\title{
Blended Learning - frem mod en ny normal på ungdomsuddannelserne
}

\author{
Michael Lund-Larsen, eVidenCenter \\ Søren Jørgensen, eVidenCenter \\ Bent B. Andresen, Aarhus Universitet, DPU
}

\begin{abstract}
Artiklen fokuserer på, hvordan corona-nedlukning af den fysiske undervisning på ungdomsuddannelserne har ændret forudsætningerne for at implementere blended learning fremover. Disse ændrede forudsætninger forstås som en udvikling af holdninger og erfaringer hos lærere, og udviklingen er sket i kraft af, at omstændighederne har tvunget lærerne til at afprøve kombinationer af læringsteori, metoder og teknologi for at gennemføre fjernundervisning. I artiklen præsenteres resultater af en analyse af data fra en rundspørge på i alt 55 skoler. Konklusionen er, at $6 \mathrm{ud}$ af 10 lærere er blevet digitalt innovative. De har været i stand til at udnytte digitale muligheder i en ekstraordinær situation og gjort sig erfaringer med nye måder at vejlede og differentiere på i undervisningen samt med alternativer til lærerstyret, formidlingsbaseret undervisning, som de forventer at overføre til en normal situation. Vi peger på blended learning som en ny normaltilstand, hvor digitalt innovative lærere, som nu findes på alle skoler, eksperimenterer med egen praksis, deler viden med kolleger og tager aktiv del i implementering af nye måder at undervise med it på.
\end{abstract}

\section{English abstract}

The concern of this article is a change in the prerequisites to implement blended learning in Danish youth education. The empirical research focuses on attitudes and experiences among teachers who employed a mix of theories and methods as well as digital technologies to enhance student learning outcome during the first period of the Covid-19 lockdown. The article presents analysed results of a survey on 55 institutions. The conclusion is that 6 out of 10 teachers have become digital innovative. In an extraordinary situation, they have been capable of exploiting technological opportunities and gained experience with new ways to guide students and practice differentiated teaching together with alternatives to directed, teacher centered teaching. The teachers anticipate to transfer their newly gained experience to their future tuition when lockdown limitations are a thing of the past. This points to blended learning as a new normal with digital innovative teachers as visionary trendsetters in every school. When school managers provide the right conditions for experimentation and sharing of knowledge, they also enable the visions of digital innovative teachers to unfold in the schools. 


\section{Indledning}

En lang række undersøgelser har i det seneste år forsøgt at afdække lærernes erfaringer med virtuel undervisning på baggrund af den fjernundervisning, som blev gennemført som nødundervisning under corona-nedlukningen i foråret 2020 (se fx Georgsen m.fl. 2021, Qvortrup 2020, GL 2020, NCE 2020). Undersøgelserne har samstemmende konkluderet, at elevernes trivsel var udfordret, og at læringsudbyttet i hovedsagen var ringere end under den "normale" undervisning, der gik forud for corona-pandemien. Derimod har der ikke været klarhed over, i hvilken udstrækning der er opnået erfaringer fra perioden, som kan åbne for større udnyttelse af et muligt digitalt potentiale i undervisningen fremover.

Denne artikel analyserer holdninger og erfaringer, der er opnået hos lærere på ungdomsuddannelserne, som i undersøgelsen Fjernundervisningstemperatur (DEA og eVidenCenter, 2020) angav, at de er positive over for digitalt medieret undervisning i deres fag samt positive over for at overføre deres erfaringer til fremtidig undervisning under normale omstændigheder. Artiklen analyserer samtidig, hvilke faktorer der har påvirket lærernes holdning til digitalt medieret undervisning og anvendeligheden af deres erfaringer.

På baggrund af denne analyse diskuteres, hvordan disse erfaringer kan bringes i spil i en fremtidig blended learning-kontekst. Et nyere forsøg på at definere blended learning fremhæver lærerens dømmekraft som et væsentligt element (Cronje 2020). Vi diskuterer, at dette kan blive et springende punkt for at komme tilbage til - og videre med - undervisningen på grundlag af de erkendelser, de fysiske nedlukninger har medført.

Dermed lyder artiklens forskningsspørgsmål: Hvilke fordele ved fjernundervisning oplevede lærerne under nedlukningen, og hvordan kan blended learning være en måde at drage nytte af disse fordele fremover på ungdomsuddannelserne?

\section{Artiklens baggrund, data og databehandling}

Artiklen er blevet til på grundlag af et samarbejde mellem Det Nationale Videncenter for e-læring (eVidenCenter) og Tænketanken DEA. Samarbejdet har omfattet lærer- og elevrettede spørgeskemaundersøgelser samt analyser og præsentationer af resultaterne. Formålet har været at lave et "aftryk" af undervisningen på ungdomsuddannelserne i en historisk exceptionel situation mellem 27. april og 8. maj 2020 (DEA og eVidenCenter 2020). Det skulle bidrage til, at alle med interesse i og ansvar for ungdomsuddannelserne undervejs og efterfølgende kunne overveje, hvordan lærere og elever bedst muligt kunne vende tilbage og komme videre med ordinær skolegang.

\section{Data og dataindsamling}

Samtlige danske ungdomsuddannelsesinstitutioner er blevet inviteret til at deltage gratis i undersøgelserne, der i praksis er gennemført som en digital spørgeskemaundersøgelse på 55 deltagende institutioner.

Spørgeskemaet er opbygget af lukkede spørgsmål med faste svarskalaer og åbne spørgsmål, der giver mulighed for at svare mere frit med egne ord. Spørgsmålene fokuserer primært på respondentens vurdering af, hvordan vedkommende selv har planlagt, gennemført og evalueret undervisning de seneste to arbejdsuger før tidspunktet for besvarelsen.

Det giver spørgeskemaet en karakter af at være a self-report questionnaire (Demetriou m.fl. 2015). Mens selvafrapportering kan siges at give mere præcis viden om underviserens praksis og refleksion over egen praksis end fx elevers og andre observatørers observationer (Burns m.fl. 1986), er der 
validitetsproblemer med at stole på "hvad folk siger om sig selv" (Paulhus m.fl. 2007, s. 228). Normer og værdier, som præger den sociale virkelighed fx inden for en profession som underviser, giver metoden en social desireability bias (Demetriou m.fl. 2015, s. 1), der påvirker respondenter til at svare mere socialt acceptabelt, end hvad praksis måske er. Det betyder, at vi i artiklen tager forbehold for, at besvarelserne ikke er socialt og kulturelt neutrale men påvirket af den sociale virkelighed, de er afgivet i.

Det er ledere på de enkelte skoler, der indledningsvist har givet samtykke til at lade undersøgelsen gennemføre, og herefter er det de samme ledere, der har haft til opgave at opfordre deres medarbejdere til logge ind og besvare spørgeskemaet. Hver leder har kunnet logge ind og følge med i antallet besvarelser samt trække rapporter med skolens svarfordelinger på de enkelte skalaspørgsmål. Det kan tyde på, at ledernes incitament for at melde skoler til undersøgelsen har været et oplevet behov for at følge med i en ukendt og usikker situation på egen skole.

Artiklen bygger på besvarelser fra 1866 lærere fordelt på uddannelserne EUD, EUX, HF, HHX, HTX og STX. I 2018/19 var der i alt ca. 17.300 lærere på ungdomsuddannelserne fordelt med ca. 14.600 på 145 gymnasiale uddannelsessteder (STX, HTX, HHX, EUX, HF) og ca. 2.700 på erhvervsuddannelserne på 83 erhvervsskoler (EUD) (GL, 2019; tal fra Uddannelsesforbundet gengivet i Redanz, 2018). I undersøgelsen deltog 45 gymnasiale uddannelsessteder og 25 erhvervsskoler (15 skoler dækker begge områder). Da antallet af lærere ikke er ændret væsentligt i 2020, og hvis det antages, at de deltagende skoler fordeler sig gennemsnitligt, var der i alt ca. 5.325 lærere på de 55 deltagende skoler, hvilket giver en estimeret svarprocent for de 1.866 respondenter på ca. 35\%.

Undersøgelsens deltagere er altså ikke repræsentative for lærere på danske ungdomsuddannelser - de udgør en såkaldt convienience sample (Given 2008), der ganske enkelt og bekvemt består af respondenter, som har været villige til at deltage. Det skal derfor understreges, at analyser og konklusioner i artiklen i princippet alene vedrører denne gruppe af respondenter.

\section{Databehandling}

I artiklen præsenterer og analyserer vi to typer af data: kvantitative data som procentuelle fordelinger samt grupperinger af svar på skalaspørgsmål og kvalitative data som fritekstbesvarelser, der er afgivet af den gruppe af respondenter, som vi fokuserer på i artiklen. Kvantitative data gør os i stand til at vurdere udstrækningen og relevansen af vores problemfelt (Kruuse 1999), nemlig hvor stor en andel af respondenterne der oplevede fordele ved undervisning under nedlukningen. Vi benytter krydstabulering mellem svar på forskellige spørgsmål for at fordele vores respondenter i kategorier af mere og mindre innovative lærere, og for at vi kan pege på tendenser til sammenfald mellem svar inden for kategorier af respondenter. Vi behandler kvalitative data i form af fritekstbesvarelser fra $60 \%$ af respondenterne, og vi vægter dermed subjektive vurderinger og betragtninger af egen praksis højt for med empirisk belæg at kunne rubricere de konkrete fordele, lærerne skriver om, i den teoretiske firfeltsmodel, vi også præsenterer i artiklen. Fritekstbesvarelserne er kodet ud fra en kodningsstrategi (Kruuse 2007), hvor tematiske overskrifter, der passer til det teoretiske hovedemne "it og didaktik", knyttes til udsagn fra respondenterne.

\section{Teoretisk ramme}

Teorirammen er udvalgt med særligt henblik på at analysere fordele og ulemper knyttet til online learning og blendend learning set fra et lærerperspektiv. I den teoretiske ramme indgår derfor teori om lærernes syn på, om og i hvilket omfang blended learning bør anvendes fremover på ungdomsuddannelserne, samt hvilke fordele og ulemper det i givet fald vil medføre for både lærernes undervisning og elevernes læring. 
I fokus er nærmere bestemt lærernes læringssyn, der i denne sammenhæng er defineret som deres syn på, hvilke aktiviteter der er bedst egnet til at fremme læring blandt eleverne, og som selvsagt præger deres didaktiske overvejelser. Særligt præger det deres overvejelser om tilrettelæggelse inkl. adgang til digitale materialer og tjenester, gennemførelse inkl. vejledning samt evaluering inkl. dokumentation. Desuden præger det lærernes vægtning af undervisningens grundformer. På dette punkt omfatter den teoretiske ramme H. Meyers (2014) teori om to grundformer, nemlig henholdsvis lærerstyrede og elevstyrede aktiviteter.

Disse to grundformer udgør en organisatorisk dimension i læringssynet. En anden dimension vedrører omfanget af fysisk tilstedeværelse. Denne dimension omfatter ligeledes to hovedformer, nemlig henholdsvis fysisk tilstedeværelse på matrikelskolen og digitalt medieret tilstedeværelse (online tilstedeværelse). Den førstnævnte tilstedeværelsesform er typisk skemalagt, mens den sidstnævnte kan være både synkron og asynkron. Forskerne Means, Toyama, Murphy \& Bakia (2013) har publiceret resultaterne af en omfattende meta-analyse, som sammenligner forløb organiseret som blended learning med forløb, der er organiseret som udelukkende tilstedeværelses- eller online-undervisning, og som peger på en signifikant forbedring af bl.a. K-12 elevers præstationer. Forskergruppen definerer selve begrebet blended learning som: Læring, der baserer sig på en kombination af online-erfaringer og erfaringer i fysiske klasserum, hvor eleverne i mindst $25 \%$ af tiden - men ikke udelukkende - lærer via Internet. Som følge af tilhørende tendenser til øget elevtid til læringsaktiviteter og øget brug af digitale læringsressourcer og tjenester, som tilskynder til indbyrdes interaktion blandt eleverne, kan det også tænkes at være disse faktorer, der bidrager til de omtalte forbedringer af elevpræstationer. Forskergruppen konkluderer, at der er vægtige argumenter for at investere i udvikling af blended learning, hvor man ikke blot udbyder traditionelle kurser online, men re-designer dem for dels at inkorporere flere online-læringsmuligheder, dels at bevare elementer af tilstedeværelsesundervisning.

Opdelingen med de omtalte dimensioner giver anledning til en firfeltsmodel, som er vist i skema 1.

Skema 1. Aktivitetsprofiler

\begin{tabular}{|c|c|c|}
\hline & Fysisk tilstedeværelse & Online tilstedeværelse \\
\hline Overvejende lærerstyret & A1 & B1 \\
\hline Overvejende elevstyret & A2 & B2 \\
\hline
\end{tabular}

I artiklen er der fokus på pædagogisk omstilling, som bygger på:

* Erfaringer med omstilling fra overvejende fysisk tilstedeværelse til ren online-undervisning under corona-nedlukningerne

* Muligheder for at udnytte disse erfaringer og det bedste fra de to tilgange ved implementering af blended learning efter genåbningen af skolernes fysiske læringsmiljøer.

Sidstnævnte omstilling repræsenterer til en vis grad et didaktisk nybrud. Eksempelvis er uddannelsesområdet kendetegnet ved mere eller mindre nidkært at registrere elevfravær, selv om det længe har været kendt, at det i mindre grad gælder om, at eleverne er til stede, og i højere grad gælder om, at de er helt med (Gadamer, 2000).

Brud med didaktisk vanetænkning er under vanlige omstændigheder ofte noget, som lærerne medvirker til under indtryk af skiftende elevforudsætninger, forventninger til deres læringsudbytte og reformer på området. I foråret 2020 var der imidlertid krav om, at skolernes fysiske læringsmiljøer lukkede brat ned. Drivkræfterne i den didaktiske omstilling var i dette tilfælde ikke lærerne selv, men da matrikelskolerne genåbnede efter to bølger med coronaen, kunne de igen rette opmærksomheden mod at skabe et velfungerende blend af online-aktiviteter og aktiviteter baseret på fysisk fremmøde. I den forbindelse kunne de udnytte, at de i mellemtiden havde haft en meget stejl læringskurve, hvor de på kort tid havde gjort en masse erfaringer med ren online-undervisning, som fortsat kan præge deres nuværende 
læringssyn, herunder særligt deres syn på blended learning. Dette må forventes at påvirke lærernes ideer om fremtidige former for blended learning i tilknytning til den undervisning, de forestår.

Et er imidlertid, at lærerne således får nye ideer om realisering af potentialerne ved blended learning, men noget andet er, om de også forventer selv at kunne realisere disse ideer i nær fremtid. Den gruppe af lærere, som umiddelbart forventer at drage nytte af deres erfaringer med online-aktiviteter under corona-nedklukningen og implementere blended learning, som de anser relevant og praktisk mulig, betegnes i det følgende digitalt innovative lærere. Betegnelsen er inspireret af terminologien af en sammenfattende rapport om ILE-projekter (OECD, 2015)). ILE er en forkortelse for Innovative Learning Environments. Projektet har bl.a. undersøgt forudsætninger for at skabe innovative læringsmiljøer for børn og unge, hvilket omfatter kulturændringer i skolerne, kapacitetsopbygning og samarbejde blandt lærerne og kommunikation ved brug af digitale platforme og tjenester. Rapportens terminologi har været en inspirationskilde ved tilblivelsen af denne artikel. Da den netop har fokus på læreres holdninger til blended learning, anvender vi begrebet digitalt innovative lærere til at betegne lærere, som udtrykker sig positivt om at re-designe rammerne for undervisning ved at realisere blended learning-scenarier.

Deres erfaringer præger deres didaktiske overvejelser over planlægning, gennemførelse og evaluering af undervisnings- og læringsforløb. De udnytter nærmere bestemt deres metodefrihed til at vælge undervisningsmetoder, som de anser for at være de mest hensigtsmæssige blandinger af fremmøde- og onlineaktiviteter. Helt konkret skifter de fokus fra aktiviteter, som i skema 1 er beskrevet som henholdsvis A1 og A2, til aktiviteter, som i skemaet er angivet som "B1" og "B2". For eksempel kan dele af "A1" blive digitaliseret og blive omstillet til dele af "B1", fordi læreren beslutter at introducere eleverne til nyt stof eller nye opgaver ved brug af digitale videoklip eller indhold på en digital materialeplatform. Tilsvarende kan det medføre ændringer af både indholdet og omfanget af de aktivitetsformer, der i skema 1 er angivet som "A2" og "B2".

Teoretisk set kan pædagogisk innovation forstås som det at få en ny idé om pædagogisk praksis og efterfølgende realisere den (Rogers, 2003). Ideen behøver ikke at være ny i objektiv forstand, men implementeringen af den skal være ny for lærerne. I dette tilfælde omfatter det ideen om blended learning, som de fleste lærere har hørt om, men som en mindre del (17\% iflg. DEA og eVidenCenter, 2020) havde førstehåndserfaringer med at tilrettelægge og gennemføre før efter to bølger med coronaen.

Der er forskningsmæssigt belæg for, at innovationer udbredes med varierende hastighed, idet nogle aktører er relativt hurtige til at tage ideerne til sig og gå i gang med at realisere dem, mens andre har brug for længere betænkningstid, før de gør det. Inspireret af innovationsteori skelnes der i det følgende mellem forskellige aktørgrupper begyndende med dem, der er hurtige til at omsætte nye ideer i praksis og sluttende med dem, der skynder sig langsomt med at adoptere nytænkning. De omtalte grupper betegnes henholdsvis:

$$
\begin{aligned}
& * \text { nyskabere + tidlige tilsluttere } \\
& * \text { det tidlige flertal } \\
& * \text { det sene flertal } \\
& * \text { efternølere }
\end{aligned}
$$

Så længe en idé endnu er ny, omfatter grupperne 'nyskabere' og 'tidlige tilsluttere' tilsammen typisk en sjettedel af en aktørgruppe. 'Det tidlige flertal' omfatter en tredjedel af den samlede gruppe. Det samme gør 'det sene flertal', mens 'efternølerne' omfatter en sjettedel (ibid.). I det følgende vil det blive sammenholdt med lærernes forventninger om at omstille til blended learning. Herved bliver det muligt at vurdere, hvorvidt der - om overhovedet - er tegn på et nybrud med hensyn til at udnytte de fordele ved blended learning, der som før omtalt er forskningsmæssigt belæg for. 


\section{De digitale innovative lærere}

For at forstå hvilke af lærernes erfaringer, der kan åbne for større udnyttelse af et muligt digitalt potentiale i undervisningen fremover, er der fokus i artiklen på lærernes besvarelse af to udvalgte spørgsmål fra undersøgelsen blandt lærere (DEA og eVidenCenter, 2020):

1. "I hvilken grad vurderer du, at fjernundervisning egner sig til det fag, du har undervist mest i?"

2. "I hvilken grad forventer du på nuværende tidspunkt at kunne overføre erfaringer med fjernundervisning og digitale undervisningsteknologier ifm. corona-nedlukningen til udvikling og gennemførsel af undervisning under normale omstændigheder?”

68\% af lærerne vurderer, at fjernundervisning i høj eller nogen grad egner sig til det fag, de har undervist mest i, mens $78 \%$ af lærerne i høj eller nogen grad forventer at kunne overføre erfaringer fra fjernundervisning og digitale undervisningsteknologier ifm. corona-nedlukningen til udvikling og gennemførsel af undervisning under normale omstændigheder.

Tabel 1. Svarfordeling blandt lærere. N=1866 (DEA og eVidenCenter 2020)

\begin{tabular}{|l|c|c|c|c|c|}
\hline $\begin{array}{l}\text { Spørgsmål, der danner grundlag for gruppering af } \\
\text { lærere i forhold } \\
\text { til "gode erfaringer" }\end{array}$ & $\begin{array}{c}\text { I høj } \\
\text { grad }\end{array}$ & $\begin{array}{c}\text { I nogen } \\
\text { grad }\end{array}$ & $\begin{array}{c}\text { I lav } \\
\text { grad }\end{array}$ & $\begin{array}{c}\text { Slet } \\
\text { ikke }\end{array}$ & $\begin{array}{c}\text { Intet } \\
\text { svar }\end{array}$ \\
\hline $\begin{array}{l}\text { I hvilken grad vurderer du, at fjernundervisning } \\
\text { egner sig til det fag, } \\
\text { du har undervist mest i? }\end{array}$ & $10 \%$ & $58 \%$ & $27 \%$ & $4 \%$ & $1 \%$ \\
\hline $\begin{array}{l}\text { I hvilken grad forventer du på nuværende } \\
\text { tidspunkt at kunne overføre erfaringer med } \\
\text { fjernundervisning og digitale } \\
\text { undervisningsteknologier ifm. corona- } \\
\text { nedlukningen til udvikling og gennemførsel af } \\
\text { undervisning under normale omstændigheder? }\end{array}$ & $26 \%$ & $52 \%$ & $16 \%$ & $3 \%$ & $4 \%$ \\
\hline
\end{tabular}

Svarene på det første spørgsmål angiver i denne sammenhæng lærernes "holdning til fjernundervisning", hvor svarkategorierne: I høj grad/I nogen grad markerer, at læreren er "Positiv over for fjernundervisning", mens "I lav grad/Slet ikke" markerer "Skeptisk over for fjernundervisning".

Svarene på det andet spørgsmål angiver lærernes "holdning til at overføre erfaringer", hvor svarene I høj grad/I nogen grad markerer, at læreren er "Positiv over for at overføre erfaringer", mens "I lav grad/Slet ikke" markerer "Skeptisk over for at overføre erfaringer".

På den måde kan lærernes besvarelse grupperes i fire kategorier:

1. Er positiv over for fjernundervisning og positiv over for at overføre erfaringer

2. Er positiv over for fjernundervisning men skeptisk over for at overføre erfaringer

3. Er skeptisk over for fjernundervisning men positiv over for at overføre erfaringer

4. Er skeptisk over for fjernundervisning og skeptisk over for at overføre erfaringer

Lærerne fordeler sig således i de fire kategorier: 
Tabel 2. Svarfordeling blandt fire "grupper" af lærere. N=1777 (DEA og eVidenCenter 2020)

\begin{tabular}{|l|c|c|}
\hline $\begin{array}{l}\text { Lærernes holdning til fjernundervisning og til at kunne overføre erfaringer til } \\
\text { undervisning under normale omstændigheder }\end{array}$ & Andel & Antal \\
\hline Er positiv over for fjernundervisning og positiv over for at overføre erfaringer & $60 \%$ & 1062 \\
\hline $\begin{array}{l}\text { Er positiv over for fjernundervisning men skeptisk over for at overføre } \\
\text { erfaringer }\end{array}$ & $9 \%$ & 156 \\
\hline $\begin{array}{l}\text { Er skeptisk over for fjernundervisning men positiv over for at overføre } \\
\text { erfaringer }\end{array}$ & $21 \%$ & 371 \\
\hline Er skeptisk over for fjernundervisning og skeptisk over for at overføre erfaringer & $11 \%$ & 188 \\
\hline
\end{tabular}

Gruppen af lærere, der er positive over for fjernundervisning og positive over for at overføre erfaringer, udviser tegn på at have taget en ny idé om pædagogisk praksis (digital læring) til sig, som de giver udtryk for, at de efterfølgende vil realisere (Rogers, 2003). I denne artikel har vi som før omtalt valgt at betegne denne gruppe lærere digitalt innovative lærere, og det er i denne gruppe, vi kigger på, hvilke erfaringer, lærerne selv peger på, kan videreføres i undervisningen under "normale" omstændigheder. Gruppen udgør 60\% af alle respondenterne (DEA og eVidenCenter, 2020). En række spørgsmål i undersøgelsen gør det muligt at analysere, hvilke faktorer der kan have betydning for lærernes placering som digitalt innovativ lærer.

Analysen peger på, at erfaring med og adgang til digitale teknologier i undervisningen inden coronanedlukningen kan have positiv betydning for holdningen til fjernundervisning og overførbare erfaringer. Fx angiver kun 9\% af dem, der tilhører gruppen af de digitalt innovative lærere, at de har et lavt eller slet intet kendskab til digitale teknologier, der er relevante for fjernundervisning, mens dette gælder for $31 \%$ af dem, der er skeptiske over for både fjernundervisning og at overføre erfaringer.

Tabel 3. Svarfordeling i hver af de fire grupper på spørgsmål om kendskab til relevant digital teknologi. N=1866 (DEA og eVidenCenter 2020)

\begin{tabular}{|l|c|c|c|}
\hline $\begin{array}{l}\text { I hvilken grad passer følgende udsagn på dine oplevelser med } \\
\text { fjernundervisning under corona-nedlukningen? Jeg har et godt } \\
\text { kendskab til digitale teknologier, der er relevante for } \\
\text { fjernundervisning! }\end{array}$ & $\begin{array}{c}\text { I høj } \\
\text { eller } \\
\text { nogen } \\
\text { grad }\end{array}$ & $\begin{array}{c}\text { I lav } \\
\text { grad } \\
\text { eller slet } \\
\text { ikke }\end{array}$ & Antal \\
\hline $\begin{array}{l}\text { Er positiv over for fjernundervisning og positiv over for at overføre } \\
\text { erfaringer }\end{array}$ & $91 \%$ & $9 \%$ & 1062 \\
\hline $\begin{array}{l}\text { Er positiv over for fjernundervisning, men skeptisk over for at } \\
\text { overføre erfaringer }\end{array}$ & $85 \%$ & $15 \%$ & 156 \\
\hline $\begin{array}{l}\text { Er skeptisk over for fjernundervisning, men positiv over for at } \\
\text { overføre erfaringer }\end{array}$ & $78 \%$ & $22 \%$ & 371 \\
\hline $\begin{array}{l}\text { Er skeptisk over for fjernundervisning og skeptisk over for at } \\
\text { overføre erfaringer }\end{array}$ & $69 \%$ & $31 \%$ & 188 \\
\hline
\end{tabular}

Den samme tendens gælder for spørgsmålene: "Jeg har adgang til digitale teknologier, der er relevante for fjernundervisning", og "Jeg har viden om, hvordan jeg kan bruge digitale teknologier i min undervisning".

Det er undersøgt, i hvilken udstrækning skolens støtte og rammer for lærerens arbejde er sammenfaldende med holdningen til fjernundervisning og overførbare erfaringer ved at stille spørgsmål såsom "Jeg har modtaget nyttige og tilstrækkelige retningslinjer for fjernundervisning fra skolen". Andelen af de digitalt innovative lærere er større (61\%) blandt dem, der har modtaget en sådan støtte i høj eller nogen grad end blandt de lærere, der i lav grad eller slet ikke har modtaget en sådan støtte (44\%). 
Det samme svarmønster kan aflæses af de tre andre spørgsmål, der omhandler skolens støtte: ”Jeg har modtaget nyttig og tilstrækkelig støtte og vejledning fra skolen ift. valg og/eller brug af digitale teknologier", "Skolen har organiseret deling af viden og erfaring med fjernundervisning mellem kolleger", samt "Skolen har organiseret deling af materialer og/eller undervisningsforløb mellem kolleger".

Det er bredt anerkendt, at skolens ledelsesmæssige fokus på digitalt medierede læringsformer, herunder lærernes rammer, forudsætninger og teknologiadgang, har betydning for lærernes anvendelse af it i undervisningen (se fx EVA 2020 og NCE 2020). Analysen peger på, at der kan være perspektiv i yderligere analyser af de konkrete sammenhænge mellem ledelsens fokus og lærernes holdning til digitalt medierede læringsformer.

\section{Positive erfaringer med digitalt medierede læringsformer}

Hvad er positive erfaringer? I denne artikel afgrænses det til positive erfaringer fra undervisningen under corona-nedlukningen, som de digitalt innovative lærere videregiver i uddybende fritekstsvar til spørgsmålet "I hvilken grad forventer du på nuværende tidspunkt at kunne overføre erfaringer med fjernundervisning og digitale undervisningsteknologier ifm. corona-nedlukningen til udvikling og gennemførsel af undervisning under normale omstændigheder?”.

Der i alt afgivet 362 (34\%) kommentarer i tilknytning til spørgsmålet fra de 1062 digitalt innovative lærere. Kommentarerne peger bortset fra ganske få (3) på positive erfaringer, der kan videreføres.

Kommentarerne fordeler sig inden for fem temaeri:

Tabel 5. Kodenøgle af fritekstbesvarelser fra de digitale innovative lærere. $\mathrm{N}(\mathrm{i}$ alt $)=362$. kommentarer kan være kodet inden for flere temaer (DEA og eVidenCenter 2020)

\begin{tabular}{|l|l|c|}
\hline \multicolumn{1}{|c|}{ Tema } & \multicolumn{1}{|c|}{ Kode } & Andel \\
\hline $\begin{array}{l}\text { Tilrettelæggelse af undervisningen (navnlig } \\
\text { målgruppeforudsætninger, rammesætning og } \\
\text { organisering) }\end{array}$ & Forløbsplanlægning & $21 \%$ \\
\hline $\begin{array}{l}\text { Præsentation af nyt stof/teori (navnlig omlægning fra } \\
\text { mundtlige læreroplæg til digitale oplæg, der sættes i } \\
\text { spil asynkront) }\end{array}$ & Oplæg og instruktioner & $29 \%$ \\
\hline $\begin{array}{l}\text { Vejledning og stilladsering af elevernes læreproces } \\
\text { (både individuelt og gruppebaseret) }\end{array}$ & Elevvejledning & $22 \%$ \\
\hline $\begin{array}{l}\text { Elevernes samarbejdsformer (både gruppearbejde og } \\
\text { gruppediskussion) }\end{array}$ & Elevsamarbejde & $17 \%$ \\
\hline $\begin{array}{l}\text { Dokumentation af læreproces og udbytte } \\
\text { fremlæggelse, procesdokumentation og } \\
\text { produktpræsentation) }\end{array}$ & Evaluering & $24 \%$ \\
\hline
\end{tabular}

De fem temaer relaterer sig på forskellig vis til teoriafsnittets aktivitetsprofiler.

Temaet "Forløbsplanlægning" peger på nogle generelle erfaringer om, hvad der bør gælde for rammesætning og organisering af aktiviteter uanset om de gennemføres ved fysisk eller online tilstedeværelse og uanset om aktiviteterne er overvejende lærer- eller elevstyrede.

I temaet “Oplæg og instruktioner” peger lærernes erfaringer på aktiviteter, der med fordel kan overvejes ændret fra overvejende lærerstyrede fysiske tilstedeværelsesaktiviteter til overvejende elevstyrede online tilstedeværelsesaktiviteter (fra A1 til B2 i firfeltsmodellen). 
Lærernes erfaringer under temaet elevvejledning peger på aktiviteter, der med fordel kan overvejes ændret fra lærerstyrede fysiske tilstedeværelsesaktiviteter til online tilstedeværelsesaktiviteter, der i nogen udstrækning også flyttes til overvejende elevstyring (fra A1 til B1 og i nogle tilfælde B2 i forfeltsmodellen).

I temaet "Elevsamarbejde" kan visse samarbejdsformer for eleverne efter lærernes erfaringer med fordel overvejes gennemført elevstyret ved online tilstedeværelse i stedet for ved fysisk (fra A2 til B2 i firfeltsmodellen).

Endelig peger lærernes erfaringer på, at aktiviteter inden for temaet "Evaluering" med fordel kan overvejes flyttet fra fysisk tilstedeværelse til online tilstedeværelse og i visse tilfælde også fra lærerstyring til elevstyring (fra A1 til B1 og A2 til B2 og i visse tilfælde fra A1 til B2 i firfeltsmodellen).

\section{Forløbsplanlægning}

Nedenstående citater er typiske eksempler på de didaktiske erkendelser, som 21\% af kommentarerne omfatter, hvor lærerne reflekterer over ændringer i deres undervisningspraksis på baggrund af deres erfaringer med fjernundervisning.
"Jeg har fået ekstra fokus på de svage og stærke elevers forskellige arbejdstempo og vil gerne arbejde endnu mere med undervisningsdifferentiering fremadrettet. Jeg vil fortsat have stort fokus på variation af undervisningen." (Kvindelig lærer, HHX)
"Opbygningen af læringsmål og krav til den praktiske opgave samt gennemgang af det teoretiske materiale i denne forbindelse, er jeg blevet mere bevidst om." (Mandlig lærer på EUD/Teknologi, byggeri og transport).

Generelt har lærergruppen gjort erfaringer vedr. forløbsplanlægning, som omfatter:

* øget undervisningsdifferentiering for at tage hensyn til forskelle i elevforudsætninger

* klar rammesætning og tydelighed om det forventede læringsudbytte, rammer for opgaveløsning og vejledning

* større fokus på undervisningens organisering - fx i form af stram og tydelig sekvensering af moduler.

Ovenstående erfaringer og deres betydning for, at lærerne vil ændre praksis, er udtryk for, at "e-læring grundlæggende har et potentiale til at skabe nye kontekster for læring og nye metoder til læring" (Hansen 2012, s. 2).

Samtidig bekræftes erfaringerne af forskning (se fx Nordahl 2010 og Hattie 2013) om, at god undervisning er kendetegnet ved tydelig struktur og variation.

Kommentarerne inden for temaet forløbsplanlægning peger på, at de digitalt innovative lærere har høstet nogle væsentlige erfaringer fra fjernundervisningen, der kan anvendes i den fremtidige strukturering af deres undervisning under normale omstændigheder, hvilket kan medvirke til at styrke den gode undervisning generelt.

\section{Pædagogiske metoder til variation}

De fire temaer oplæg og instruktion, elevvejledning, elevsamarbejde og evaluering analyseres i forhold til, om de kan medvirke til at styrke det andet kendetegn ved den gode undervisning: variation. 
Gode erfaringer med henblik på at variere undervisningen er særligt interessante, idet $68 \%$ af lærerne angiver, at undervisningen er blevet 'mere' eller 'markant mere' ensformig under corona-nedlukningen sammenlignet med undervisningen før nedlukningen (DEA og eVidenCenter 2020). Dette bekræftes af en række andre undersøgelser på ungdomsuddannelsesområdet (se fx GL 2020). Man kan tænke sig, at denne oplevelse medfører en holdning om, at fjernundervisning eller virtuel undervisning er mere ensformig end traditionel tilstedeværelsesundervisning.

En nærmere analyse viser imidlertid, at de digitalt innovative lærere i højere grad vurderede sig i stand til at fastholde eller øge variationen i deres undervisning end de øvrige lærere. Således angiver $36 \%$ blandt de digitalt innovative lærere, at deres undervisning var varieret i samme grad, mere eller markant mere under corona-nedlukningen sammenlignet med undervisningen før nedlukningen, hvor dette er tilfældet for $7 \%$ af de lærere, der er skeptiske over for både fjernundervisning og at overføre erfaringer. Med forbehold for tidligere anførte bias ved selv afrapportering bemærker vi, at der er en væsentlig forskel i, hvordan de to grupper af lærere svarer.

Tabel 6. Fordeling af de fire gruppers besvarelse af spørgsmål til graden af variation i undervisning. $\mathrm{N}=1777.89$ har ikke besvaret spørgsmålet (DEA og eVidenCenter 2020)

\begin{tabular}{|l|c|l|l|l|l|}
\hline $\begin{array}{l}\text { Hvordan vil du beskrive dine seneste to ugers } \\
\text { fjernundervisning sammenlignet med din } \\
\text { undervisning før corona-nedlukningen? }\end{array}$ & $\begin{array}{l}\text { Markant } \\
\text { mere } \\
\text { varieret }\end{array}$ & $\begin{array}{l}\text { Mere } \\
\text { varie } \\
\text { ret }\end{array}$ & $\begin{array}{l}\text { Adskill } \\
\text { er sig } \\
\text { ikke }\end{array}$ & $\begin{array}{l}\text { Mere } \\
\text { ensfor } \\
\text { mig }\end{array}$ & $\begin{array}{l}\text { Markant } \\
\text { mere } \\
\text { ensformig }\end{array}$ \\
\hline $\begin{array}{l}\text { Er positiv overfor fjernundervisning og } \\
\text { positiv overfor at overføre erfaringer }\end{array}$ & $2 \%$ & $10 \%$ & $24 \%$ & $50 \%$ & $9 \%$ \\
\hline $\begin{array}{l}\text { Er positiv overfor fjernundervisning men } \\
\text { skeptisk overfor at overføre erfaringer }\end{array}$ & $1 \%$ & $2 \%$ & $20 \%$ & $58 \%$ & $16 \%$ \\
\hline $\begin{array}{l}\text { Er skeptisk overfor fjernundervisning men } \\
\text { positiv overfor at overføre erfaringer }\end{array}$ & $2 \%$ & $4 \%$ & $8 \%$ & $53 \%$ & $29 \%$ \\
\hline $\begin{array}{l}\text { Er skeptisk overfor fjernundervisning og } \\
\text { skeptisk overfor at overføre erfaringer }\end{array}$ & $1 \%$ & $1 \%$ & $5 \%$ & $42 \%$ & $47 \%$ \\
\hline
\end{tabular}

\section{Oplæg og instruktion}

Følgende udsagn repræsenterer en gennemgående erfaring blandt mange af de 29\% kommentarer, der vedrører præsentation af nyt stof/ny teori:

"Jeg har fået lavet en masse undervisningsvideoer med fagligt indhold, som jeg vil bruge efterfølgende eller være inspireret af til at arbejde videre med Flipped Learning m.v." (Mandlig lærer, EUD/Fødevarer, jordbrug og oplevelser).

De erfaringer, de digitalt innovative lærere giver videre om temaet 'Oplæg og instruktion', kan sammenfattes til, at: 
* digital organisering og lagring af læringsmaterialer har været nødvendigt for at skabe fleksibel adgang til materialerne

* læreroplæg ( $\mathrm{fx}$ tavlegennemgang af teori eller lign.) er omlagt til optagne oplæg (indtalte Powerpoint, video eller podcast) for at skabe mere tid til diskussion og øvelser samt til repetition generelt og for særlige målgrupper (fx ordblinde), der har fordel af, at kunne tilegne sig stoffet ved gentagelse

* optagelse af instruktioner i praktiske anvendelser, så eleverne kan få hjælp 'just in time' i stedet for at skulle vente på læreren

* inddragelse af videooplæg fra eksterne eksperter, fagfolk eller lign. med henblik på at skabe autenticitet i undervisningen

Under dette tema har fokus været på at omlægge synkrone oplæg/formidling/præsentationer af teori, instruktioner og anden viden til digitale materialer, der kan anvendes og gentages igen og igen. Altså aktiviteter, der med fordel kan overvejes ændret fra overvejende lærerstyrede fysiske tilstedeværelsesaktiviteter til online tilstedeværelsesaktiviteter. Aktiviteterne kan desuden stilles til rådighed online for eleverne, så de på eget initiativ kan anvende dem til repetition, fordybelse eller når de på anden vis kunne få brug for dem.

\title{
Elevvejledning
}

Følgende citat vedr. vejledning af enkeltelever og grupper repræsenterer en gennemgående erfaring blandt de 22\% kommentarer, der vedrører elevvejledning:

\begin{abstract}
"F.eks. SRP-vejledning (vejledning om Studieretningsprojekt - red.) fungerede fint, så i fremtiden behøver eleverne måske ikke komme hele vejen til skole for at blive vejledt 15 min. Det kan klares online. Jeg har helt sikkert opdaget nogle værktøjer, som jeg vil bruge i fremtiden, f.eks. optagelse af gruppearbejde i Meet (digitalt samarbejdsværktøj med bl.a. videochat, red.)." (Kvindelig lærer, STX).
\end{abstract}

86\% af de digitalt innovative lærere vurderer, at de under nedlukningen i høj eller nogen grad har ydet deres elever tilstrækkelig vejledning og feedback i forhold til at understøtte deres læring og udvikling (DEA og eVidenCenter 2020). Dette gælder kun for $47 \%$ af de lærere, der er skeptiske over for både fjernundervisning og at overføre erfaringer.

Tabel 7. Fordeling af de fire gruppers besvarelse af spørgsmål til tilstrækkeligheden af feedback. $\mathrm{N}=1777.89$ har ikke besvaret spørgsmålet (DEA og eVidenCenter 2020)

\begin{tabular}{|l|c|c|c|c|}
\hline $\begin{array}{l}\text { I hvilken grad vurderer du, at den vejledning og feedback, du } \\
\text { har ydet til dine elever/kursister indenfor de seneste to uger } \\
\text { med fjernundervisning, har været tilstrækkelig i forhold til at } \\
\text { understøtte deres læring og udvikling? }\end{array}$ & $\begin{array}{c}\text { I høj } \\
\text { grad }\end{array}$ & $\begin{array}{c}\text { I nogen } \\
\text { grad }\end{array}$ & $\begin{array}{c}\text { I lav } \\
\text { grad }\end{array}$ & $\begin{array}{c}\text { Slet } \\
\text { ikke }\end{array}$ \\
\hline $\begin{array}{l}\text { Er positiv over for fjernundervisning og } \\
\text { positiv over for at overføre erfaringer }\end{array}$ & $16 \%$ & $70 \%$ & $13 \%$ & $0 \%$ \\
\hline $\begin{array}{l}\text { Er positiv over for fjernundervisning men } \\
\text { skeptisk over for at overføre erfaringer }\end{array}$ & $9 \%$ & $67 \%$ & $23 \%$ & $1 \%$ \\
\hline $\begin{array}{l}\text { Er skeptisk over for fjernundervisning men } \\
\text { positiv over for at overføre erfaringer }\end{array}$ & $5 \%$ & $57 \%$ & $37 \%$ & $2 \%$ \\
\hline $\begin{array}{l}\text { Er skeptisk over for fjernundervisning og } \\
\text { skeptisk over for at overføre erfaringer }\end{array}$ & $3 \%$ & $44 \%$ & $48 \%$ & $4 \%$ \\
\hline
\end{tabular}

De erfaringer, de digitalt innovative lærere giver videre om temaet 'elevvejledning', kan sammenfattes til: 
* vejledning og stilladsering af den enkelte kan ske individuelt online med henblik på differentiering og effektivisering

* feedback på andre elevers arbejde (kammerat- eller peer feedback) kan anvendes, som læringsmetode for både afsender og modtager med henblik på at øge elevernes læringsudbytte og ansvar for at bidrage til egen læring

* optagelse (video, screencast eller lign.) af eksempler på løsning af opgaver med henblik på, at den enkelte elev kan følge med i ro og fred og gentage vejledning i løsningen

* organisering af virtuelle grupper, som kan "besøges" virtuelt med henblik på onlinevejledning i processen (kan også organiseres uden fysisk adskillelse)

* eleverne kan deltage i synkrone vejledningsseancer om fx erhvervscase

Ovenstående aktiviteter kan efter de digitalt innovative læreres erfaringer med fordel overvejes ændret fra lærerstyrede fysiske tilstedeværelsesaktiviteter til online tilstedeværelsesaktiviteter, der i nogen udstrækning også flyttes til overvejende elevstyring.

\title{
Elevsamarbejde
}

17\% af kommentarerne fra de digitalt innovative lærere vedrører elevernes samarbejdsformer:

\begin{abstract}
"Ved gruppearbejde har det været fungeret godt at skabe nogle faste grupper med faste chatrum, som jeg som underviser har kunnet besøge. Det gør processen og overgangen fra klasseundervisning til gruppearbejde meget lettere." (Mandlig lærer, STX)

"Jeg [vil] formentlig fortsætte med at bruge Teams (digitalt samarbejdsværktøj med bl.a. videochat, red.) i grupper i klassen (skærmdeling i grupperne osv) og i højere grad udnytte samarbejdsområdet i OneNote (digital delelig notesbog, red.) - for de enkelte grupper incl. at tegne på OneNote." (Kvindelig lærer, Social- og Sundhedsuddannelsen).
\end{abstract}

Kommentarerne går på de digitale værktøjer, som støtte til gruppearbejde og gruppediskussioner:

* gruppearbejde, så en elev, der er småsløj, kan deltage online uden at skulle miste undervisningen

* fælles arbejde på delte dokumenter eller filer, så alle i gruppen er med hele vejen

* fælles kommunikation på gruppearbejde "ude af huset" ved fx virksomhedsbesøg eller feltstudier

* mulighed for, at alle elever kan komme til orde i skriftbaserede diskussioner i onlinekonferencer

De digitalt innovative lærere peger således på samarbejdsformer for eleverne, der efter lærernes erfaringer med fordel kan overvejes gennemført elevstyret ved onlinetilstedeværelse i stedet for ved fysisk tilstedeværelse.

\section{Evaluering}

Den digitalt innovative lærer har i nogen udstrækning høstet gode erfaringer med at dokumentere elevernes læring - både proces og resultat - digitalt:

"Har tidligere haft problemer med mundtlige fremlæggelser fra elever, der ikke tør gøre det foran klassen. De får nu lov til at gøre det fx virtuelt." (Mandlig lærer, STX). 
"Jeg vil fortsætte med at bede om små individuelle produkter i løbet af timen. Det "tvinger" alle til at gøre en indsats for at lære noget." (Mandlig lærer, STX).

$61 \%$ af de digitalt innovative lærere angiver, at deres forudsætninger for at vurdere deres elevers læringsudbytte, motivation eller arbejdsindsats er blevet markant højere, lidt højere eller er uændret i forbindelse med fjernundervisningen sammenlignet med perioden inden corona-nedlukningen (31\% angiver at deres forudsætninger er blevet markant højere eller lidt højere). Dette gælder kun for $30 \%$ af de lærere, der er skeptiske over for både fjernundervisning og at overføre erfaringer ( $8 \%$ angiver, at deres forudsætninger er blevet markant højere eller lidt højere).

Tabel 8. Fordeling af de fire gruppers besvarelse af tre spørgsmål til egen forudsætninger for at vurdere elevernes indsats, udbytte og trivsel. $\mathrm{N}=1777.89$ har ikke besvaret spørgsmålet (DEA og eVidenCenter 2020)

\begin{tabular}{|l|c|c|}
\hline $\begin{array}{l}\text { Hvordan vil du beskrive dine forudsætninger for at vurdere dine elevers } \\
\text { læringsudbytte, motivation eller arbejdsindsats inden for de seneste to uger } \\
\text { med fjernundervisning sammenlignet med perioden inden corona- } \\
\text { nedlukningen?ii }\end{array}$ & $\begin{array}{l}\text { Det samme } \\
\text { eller bedre }\end{array}$ & Dårligere \\
\hline Er positiv over for fjernundervisning og positiv over for at overføre erfaringer & $61 \%$ & $39 \%$ \\
\hline $\begin{array}{l}\text { Er positiv over for fjernundervisning, men skeptisk over for at overføre } \\
\text { erfaringer }\end{array}$ & $51 \%$ & $49 \%$ \\
\hline $\begin{array}{l}\text { Er skeptisk over for fjernundervisning, men positiv over for at overføre } \\
\text { erfaringer }\end{array}$ & $41 \%$ & $59 \%$ \\
\hline $\begin{array}{l}\text { Er skeptisk over for fjernundervisning og skeptisk over for at overføre } \\
\text { erfaringer }\end{array}$ & $30 \%$ & $70 \%$ \\
\hline
\end{tabular}

De erfaringer, som de digitalt innovative lærere vil videreføre, går på evaluering af både læringsproces og produkt:

* skriftlig dokumentation af elevernes arbejdsproces ved at lade eleverne arbejde i fællesdokumenter, så læreren kan se, hvad eleverne laver, og hvem der deler og skriver

* mundtlige elevfremlæggelser på video eller podcast for at give flere elever mulighed for at dokumentere deres læring ved mundtlig fremlæggelse

* anvendelse af digitale test og quizzer (fx med Kahoot) for at afdække, om eleverne har forberedt sig, eller om de har forstået det gennemgåede stof

* udvikling af nye differentierede opgaver, der kan anvendes fremadrettet

* afleveringsopgaver (i skolepraktik/EUD), som fokuserer på bestemte praktikmål med henblik på, at eleven kan dokumentere viden om emnet, og samtidig gøre det nemmere for instruktøren at vurdere elevernes faglige niveau

* løbende små opgaver i lektionerne for at sikre, at alle er med undervejs.

De digitalt innovative læreres erfaringer peger således på, at en række aktiviteter inden for temaet "Evaluering" med fordel kan overvejes flyttet fra fysisk tilstedeværelse til online tilstedeværelse og i visse tilfælde også fra lærerstyring til elevstyring. 


\section{Diskussion af blended learning som et nyt syn på ungdomsuddannelserne}

Hensigten i det følgende er at diskutere tre forskellige sider af lærernes erfaringer med digitalt medieret undervisning, nemlig:

1. en erfaring med, at lærernes didaktiske kompetencer bliver grundlæggende udfordret

2. øget opmærksomhed vedr. forskellene på elevernes forudsætninger og foretrukne arbejdsmåder

3. udvikling af lærernes didaktiske kompetencer som forudsætning for at styrke blended learning

For det første bragte nedlukningen af den fysiske undervisning uddannelsessystemet i Danmark i en choktilstand - i lighed med mange andre steder i verden. Den skabte nærmest en form for undtagelsestilstand, som satte mange elementer af skolens virksomhed ud af deres sædvanlige funktion og efterlod lærerne med en fordring om at forholde sig til, hvordan de kunne komme tilbage, men også til hvordan de kunne komme videre på baggrund af de erkendelser, som opstod under undtagelsestilstanden.

Vores undersøgelsesresultater og resultater af andres undersøgelser (se fx GL, 2020, NCE, 2020 og Schooleducationgateway, 2020) viser, at begivenhederne fra marts til juni 2020 har ført til nye didaktiske erfaringer og erkendelser blandt lærerne. Som nævnt rapporterer gruppen af digitalt innovative lærere mange af sådanne erkendelser. Gennem deres praktiske erfaringer med undervisningen under corona-nedlukningen fik de øget kendskab til, hvad der fungerer godt og mindre godt ved digitalt medierede læringsformer. På områderne oplæg og instruktioner, elevvejledning, elevsamarbejde og evaluering har lærerne gjort førstehåndserfaringer med nye digitale undervisningsmetoder, som de har mulighed for at inddrage i blended learning fremover.

Blandt de rapporterede konsekvenser er der særligt én gennemgående konsekvens: At læreren har gjort førstehåndserfaringer med virtuel undervisning, og at erfaringerne med, hvad dette kan bidrage med i forhold til elevernes læreprocesser, styrker deres didaktiske kompetencer på dette område. Disse kompetencer kan lærerne fremover anvende til at genoverveje organiseringen af deres undervisning og herunder de før omtalte blandingsforhold mellem dels fysisk og online tilstedeværelse, dels lærer- og elevstyrede aktiviteter.

For det andet medvirkede opbruddet i lærernes hidtidige undervisningspraksis og nødvendigheden af at gentænke denne undervisning i en ny kontekst til, at de blev opmærksomme på grupper af elever, som de ikke hidtil havde givet tilstrækkelig opmærksomhed. En af lærerne konkretiserer det på denne måde: "Jeg har fået ekstra fokus på de svage og stærke elevers forskellige arbejdstempo og vil gerne arbejde endnu mere med undervisningsdifferentiering fremadrettet."

I den pædagogiske litteratur er behovet for undervisningsdifferentiering almindeligt anerkendt, men det er også erkendt, at denne undervisningsform er svær at håndtere for lærerne (Duch, 2012). Lærernes erfaringer med, at nogle elever er "blomstret op" under corona-nedlukningen, baserer sig på, at særligt gruppen af elever, som normalt er tilbageholdende og stille eller let lader sig forstyrre i undervisningen, har haft glæde af at få mere ro og tid til fordybelse i forbindelse med onlineundervisningen under nedlukningen. Omvendt er lærerne opmærksomme på, at fraværet af fysisk samvær og begrænsede sociale relationer har betydet alvorlige trivselsudfordringer, som medførte generelle udfordringer for elevernes læreprocesser og specifikke udfordringer for de svageste elever.

Lærerne havde ikke i forvejen kendskab til digitale undervisningsmetoder, der kan kompensere for denne trivselsudfordring, og det lykkedes tilsyneladende heller ikke lærerne at finde løsninger på denne udfordring under corona-nedlukningen. Selv om motivationen for at arbejde med at skabe og 
vedligeholde relationer til eleverne i forbindelse med digitalt medierede læringsformer er blevet styrket blandt de medvirkende lærere, er der således stadig behov for at dele viden om, eksperimentere med og udvikle tiltag på dette område.

For det tredje peger de digitalt innovative lærere som nævnt selv på en række erfaringer med digitalt medierede læringsformer, som de vil bringe videre $\mathrm{i}$ den fremtidige, 'normale' tilstedeværelsesundervisning. Særligt peger de på, at de har udviklet deres didaktiske kompetencer på en måde, som styrker deres muligheder for fremover at tilrettelægge og gennemføre online-aktiviteter i sammenhæng med fysisk tilstedeværelse.

Blended learning har ofte været opfattet som skift mellem fysisk tilstedeværelses- og onlineundervisningsformer (Dau, 2020). Cronje (2020) påviser imidlertid, at kompleksiteten af blended learning går langt ud over valg mellem fysisk og digitalt medieret tilstedeværelse. Spørgsmål om didaktikkens hvordan kan derfor ikke besvares udtømmende med henvisning til det organisatoriske spørgsmål om, hvorvidt og i hvilket omfang eleverne møder lærerne og hinanden i det fysiske rum eller bag en skærm. Det omfatter også en lang række andre aspekter af lærernes didaktiske overvejelser over, hvordan elevernes aktiviteter bedst kan tilrettelægges, gennemføres og evalueres under inddragelse af online-aktiviteter, mens eleverne befinder sig i det fysiske læringsrum.

Eleverne lærer dybest set kun gennem det, de gør, og derfor må lærerne overveje, hvordan det i et givet forløb er mest hensigtsmæssigt at blande elev- og lærerstyrede aktiviteter, individuelle og kollaborative elevaktiviteter, elever med forskellige faglige forudsætninger og præferencer (jf. omtalen i det foregående af behovet for undervisningsdifferentiering) mv. Alt dette såvel som den digitale teknologi, der i dag er til rådighed på skolerne, har lærerne som nævnt gjort værdifulde erfaringer med. Særligt har flertallet af de digitalt innovative lærere gjort erfaringer med svar på didaktikkens hvordan-spørgsmål, som de kan omsætte i praksis fremover, og som kan danne afsæt for refleksioner over, hvordan de kommer videre med at fremme dannelse og uddannelse af elever på ungdomsuddannelserne. For de digitalt innovative lærere er spørgsmålet ikke om, men hvorledes de erfaringer og erkendelser, som de har gjort sig under corona-nedlukningen, kan komme i spil fremover.

\section{Konklusion}

De tre måneders corona-nedlukning med fjernundervisning i foråret 2020 indebar en stejl læringskurve inden for digitalt medierede læringsformer for lærerne på ungdomsuddannelserne. Man kan sige, at coronaen gav lærerne et kæmpe kompetenceløft på det digitale undervisningsområde, som det sandsynligvis ikke ville have være muligt at gennemføre under normale forhold så bastant og med så effektivt et resultat over så kort en periode.

De digitalt innovative lærere har opnået erfaringer med digitale undervisningsmetoder, der gør, at de mindst på samme niveau eller bedre er i stand til at vejlede, differentiere og evaluere end før coronakrisen. Og de vil videreføre erfaringer med dette i deres undervisning fremover.

Artiklen viser, at omkring $60 \%$ af deltagerne i undersøgelsen af lærernes erfaringer under coronaen har fået et positivt syn på pædagogisk innovation i form af digitalt medierede læringsformer. I undersøgelsen angiver godt $30 \%$, at de før coronaen havde opnået erfaringer med hel eller delvis fjernundervisning. Denne andel går igen i andre undersøgelser. Det ser således ud til, at der er sket en større forskydning i lærergruppens erfaringer, således at "det sene flertal”, i dag er blevet overbeviste om fordelene ved at styrke digitalt medierede læringsformer, og at de selv vil indføre blended learning e.l. i morgendagens undervisning. Det er denne gruppe lærere - 60\% i undersøgelsen - vi betegner de digitalt innovative lærere. 
Lærernes kendskab til undervisningsmetoder og deres virkning i egen undervisning er dermed udvidet væsentligt, hvilket styrker kvaliteten i deres overvejelser om en hensigtsmæssig sammensætning af læringsformer, pædagogiske metoder og teknologianvendelse i en given kontekst - i daglig tale: udøvelse af lærerens metodefrihed.

Blended learning er en måde, hvorpå lærerne fremover kan drage nytte af deres erfaringerne med fordelene ved digitale undervisningsmetoder på ungdomsuddannelserne.

Alle landets skoler med ungdomsuddannelser har været lukket ned, og de digitalt innovative lærere kan derfor med rimelighed forventes at være til stede i varierende omfang på de fleste skoler. Ved at bringe skolens lærere sammen i en dialog om erfaringerne og i eksperimenter med nye blandingsforhold af undervisningsformer, kan erfaringerne fra nedlukningen bearbejdes i et didaktiske perspektiv på en ny normaltilstand: blended learning på ungdomsuddannelserne. 


\section{Referencer}

Cronje, J.C. (2020). “Towards a New Definition of Blended Learning”, i The Electronal Journal of e-Learning, 18(2), s. 114-121.

Dau, S. (2020). “Læring på og i Blended Learning”, i Tidsskriftet Læring og Medier (LOM), 12(22) 23.

DEA og eVidenCenter (2020). Fjernundervisningstemperatur. Rapport udgivet af Det Nationale Videncenter for e-læring og Tænketanken DEA. Rapporten er tilgængelig her.

Demetriou, C., Ozer, B. U., \& Essau, C. (2015). "Self-report questionnaires”, i R. Cautin, \& S. Lilienfeld (red.), The Encyclopedia of Clinical Psychology. New York: John Wiley \& Sons, Inc.

Duch, H. S. (2012). Hvorfor er det så svært at arbejde med undervisningsdifferentering. Danske Professionhøjskoler.

EVA (2020). Digitale teknologier i undervisningen på ungdomsuddannelserne - Lærernes overvejelser om tilog fravalg. Notat udgivet af Danmarks Evalueringsinstitut. Notatet er tilgængeligt her.

Gadamer, H.-G. (2000). Teoriens lovprisning - taler og artikler. Aarhus: Systime.

Georgsen, Marianne og Qvortrup, A. (red.) (2021). Erfaringer og oplevelser med online undervisning på 9 videregående uddannelsesinstitutioner i foråret 2020. Rapport i digital version. Rapporten er tilgængelig her.

Given, Lisa (2008). "Convenience Sample", i The SAGE Encyclopedia of Qualitative Research Methods. SAGE Publications. http://dx.doi.org/10.4135/9781412963909.n68.

GL (2019), Gymnasielærere i tal 2019. Rapport i digital version. Rapporten er tilgængelig her.

GL (2020). Virtuel undervisning - Lærernes erfaringer. Medlemsundersøgelse udgivet i rapport af Gymnasieskolernes Lærerforening. Rapporten er tilgængelig her.

Hansen, J. (2012). "Tema 2: At designe e-læring - didaktiske perspektiver på uddannelsesdesign og didaktiske design", i Tidsskriftet Læring og Medier (LOM), 5(9)

Hattie, J. (2013). Synlig læring - for lærere. Dafolo

Kruuse, Emil (2007). Kvalitative forskningsmetoder - i psykologi og beslægtede fag. København Ø: Dansk Psykologisk Forlag.

Kruuse, Emil (1999). Kvantitative forskningsmetoder. I psykologi og tilgrænsende fag. København Ø: Dansk Psykologisk Forlag

Means, B., Toyama, Y., Murphy, R., \& Bakia, M. (2013). The effectiveness of online and blended learning: A metaanalysis of the empirical literature. Teachers College Record Volume 115. New York: Teachers College, Columbia University. Rapporten er tilgængelig her.

Meyer, H. (2014). Hvad er god undervisning? København: Gyldendals Lærerbibliotek.

NCE (2020). Onlineundervisning under coronakrisen. Rapport udgivet af Nationalt Center for Erhvervspædagogik, Københavns Professionshøjskole. Rapporten er tilgængelig her.

Nordahl, T. m.fl. (2010). Uligheder og variationer - Danske elevers motivation, skolefagligt læringsudbytte og sociale kompetencer. University College Nordjylland. Rapporten er tilgængelig her.

OECD. (2015), Schooling redesigned: Towards innovative learning systems - educational research and innovation. Paris: OECD Publishing. Rapporten er tilgængelig her.

Paulhus, Delroy L., Vazire, Simine (2007). “The Self-Report Method”, i Fraley, Chris, Krueger, Robert og Robins, Richard (red.) Handbook of Research Methods in Personality Psychology. London: The Guilford Press.

Qvortrup, A. m.fl. (2020). Nødundervisning under corona-krise - et elev-og forældreperspektiv. Samlet datarapport fra april 2020. DPU, Aarhus Universitet, SDU.

Redanz, Mille (2018). "På to år: erhvervsskoler har fyret hver 10. lærer”, digital artikel i Fagbladet 3F. Artiklen er tilgængelig her.

Rogers, E. M. (2003). Diffusion of innovations. Fifth Edition. New York: Free Press.

SchoolEducationGateway (2020). Brugerundersøgelse om online læring - Resultater. Rapport er tilgængelig her. 


\section{Forfattere}

\section{Søren Jørgensen}

Specialkonsulent

Det Nationale Videncenter for e-læring (eVidenCenter)

\section{Michael Lund-Larsen}

Centerchef

Det Nationale Videncenter for e-læring (eVidenCenter)
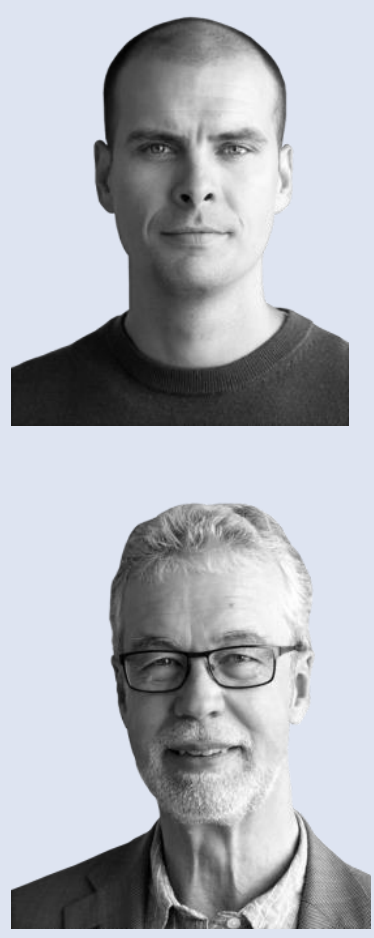

\section{Bent B. Andresen}

Lektor, Ph.D.

Aarhus Universitet, DPU

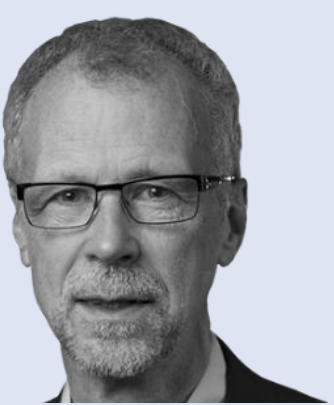


Noter

i For at kode kommentarerne, har det i nogen udstrækning være nødvendigt også at inddrage svaret på spørgsmålet "Hvad har efter din erfaring indtil videre og samlet set fungeret bedst med fjernundervisningen, som du har været involveret i under corona-nedlukningen?"

ii Tabellen viser andelen af respondenter i de fire grupper, der har angivet, at deres forudsætninger på et af de tre spørgsmål vedr. enten læringsudbytte, motivation eller arbejdsindsats er "Det samme eller bedre"

(svarkategorierne markant højere, lidt højere eller uændret) eller "Dårligere" (svarkategorierne lidt lavere eller markant lavere). 